\title{
JUDICIAL REVIEW AS A REQUIREMENT OF DUE PROCESS IN RATE REGULATION
}

\author{
Thomas P. Hardman \\ University of West Virginia Law School
}

Since the famous $\mathrm{Ju}$ Toy Case ${ }^{1}$ in America and the equally famous Arlidge Case $^{2}$ in England, there has been considerable apprehension that administrative law, as it is being developed, is gradually encroaching upon a fundamental safeguard of the liberty and property protected in England by "the rule of law" and in America by the due process clauses of the Constitution. 4 From an inarticulate training or perhaps from intuition the average Anglo-American had apparently come to feel that the fundamental law of the land requires some sort of judicial review of those administrative determinations which seriously affect one's rights with respect to liberty and property. When, therefore, he was told by the courts that one's most important rights with respect to liberty and property may, under some circumstances, be determined by administrative officers without any right of judicial review, or with a very limited right of review, he was instinctively inclined to be somewhat apprehensive. ${ }^{5}$ Within the last year, however, the United States Supreme Court, partly perhaps as a result of this apprehension, has handed down a highly important decision ${ }^{6}$ in which the Court practically eliminated the margin of finality which had apparently been accorded

${ }^{1}$ United States v. Ju Toy (I905) rg8 U. S. 253, 25 Sup. Ct. 644

"Local Goverment Board v.'Arlidge [1915, H. L.] A. C. 120.

"As to the protection secured by the so-called "rule of law" see Dicey, The Law of the Constitution ( 7 th ed. I908) I79 ff. See in this connection an interesting discussion of the Arlidge Case by Professor Dicey, The Development of Administrative Law in England (I9I5) 3I LAW QUAR. REv. I48.

" "No person shall be . . . deprived of life, liberty, or property, without due process of law." U. $\dot{U}$. Const. 5th Amendment. The I4th Amendment imposes the requirement of due process upon the several states. And there are similar provisions in the various state constitutions.

In order to avoid any misinterpretation of the context it may be well to add that the principles of due process, as understood in America, are in general applicable to English tribunals not proceeding according to express authority of Parliament. And, of course, the general principles of "the rule of law" apply, under one name or another, in the United States as well as in England.

${ }^{8}$ Some commentators have even expressed a fear that the un-Anglican droit administratif has already found a formidable footing in Anglo-American law. See Hannis Taylor, Due Process of Law (Igr5) 24 YAle LAw Journar, 353, 369. Mr. Taylor there says: "Droit administratif has no right to exist in a country in which there is due process of law or the law of the land. ... [But] under the fatal exception to the law of the land born of a lamentable misapprehension in Murray v. Hoboken Land \& Improvement Company [(1855, U. S.) I8 How. 272] we are rapidly building up a droit administratif in the United States." See also Dicey, op. cit. (IgI5) 31 LaW Quar. Rev. I48.

- Ohio Valley Water Co. v. Ben Avon Borough (Ig20) 253 U. S. 287, 40.Sup. Ct. 527 . 
to the most important class of administrative determinations, viz., administrative valuations for purposes of rate regulation.

In that case the Supreme Court held, in effect, that, where there has been a valuation by a public service commission for rate-making purposes, due process requires a right to an independent judicial re-examination of the administrative valuation. The facts of the case were as follows: A state public service commission after due notice and hearing fixed the value of a public utility for rate-making purposes. The utility appealed to the superior court of the state on the ground that the value as fixed was so low that the commission's action deprived the utility of property without due process. There was no claim of want of jurisdiction or abuse of discretion. The superior court passed upon the weight of the evidence and corrected the valuation. ${ }^{7}$ The supreme court of the state, reversing the superior court and reinstating the order of the commission, held that as there was competent evidence tending to sustain the commission's valuation and as no abuse of discretion appeared, the commission's valuation should be considered final. ${ }^{8}$ The United States Supreme Court, reversing the supreme court of the state, held that, since the state public service act, as construed by the supreme court of the state, did not permit a judicial review in which the reviewing court could exercise its independent judgment as to the valuation of the utility, it violated the due process clause of the Fourteenth Amendment. Justices Brandeis, Holmes, and Clarke dissented on the ground, inter alia, that, in this respect, due process requires no more than a review of the question "whether there was evidence on which the "valuation adopted could reasonably have been made."

The question, then, is: To what extent, if any, does due process require a judicial review of administrative valuations, particularly administrative valuations for purposes of rate regulation? In order to. answer this question adequately it will first be necessary to determine the precise nature of the action of a public service commission in making such a determination. Is such action legislative, executive, or judicial? Or is it a practical union of these so-called "three powers" of government-a sort of "fourth power?": It does not aid us much to call it, as it is commonly called, "administrative" action.

For the sake of argument let us assume that due process requires a judicial determination of the question of proper valuation for purposes of rate regulation. It by no means follows that there must be a judicial review of'a valuation made by a public service commission; for, accord-

\footnotetext{
'Ben Avon Borough v. Ohio Valley Water Co. (IgI7) $68 \mathrm{~Pa}$. Super. Ct. 56r.
}

${ }^{8}$ Ben Avon Borough et al. v. Ohio Valley Water Co. (No. I) (1918) $260 \mathrm{~Pa}$. 289, 103 At1. 750.

- See Edward A. Harriman, The Development of Administrative Law in the United States (1916) 25 Yale Law Journal, 658, 659: "From the standpoint of the function which they perform, there are four kinds of officers, and not three, and the administrative function supplements the executive, legislative and judicial functions." 
ing to the better view, the modern public service commission acts judicially, ${ }^{10}$ as well as legislatively and executively. ${ }^{11}$ But does such a commission act judicially when, in making a valuation for rate-making purposes, it determines that the rate which it bases on such valuation is a reasonable and, therefore, non-confiscatory rate?

The United States Supreme Court held in the well-known Prentis Case $^{12}$ that such action is not judicial action. But can such a holding be supported? If, after a commission has fixed a rate, a court is called upon to determine whether the rate is reasonable (i.e., whether the rate permits the utility to earn a reasonable return upon the fair value of its property), it is well settled today that such a determination involves judicial action..$^{13}$ So, if a commission after fixing a rate were empowered to make such a determination, it would clearly be a judicial determination. Now, if such a subsequent determination of that question is judicial action, why is not a contemporaneous determination of that question just as much judicial action? In each case there are contesting parties, there is due notice and a hearing substantially the same as in an ordinary court trial, and in each case the object is, in practical effect, to determine the jural relations ${ }^{14}$ of contestants as they

${ }^{10}$ See e. g., Interstate Commerce Commission v. Cincinnati etc. Ry. Co. (1897) I67 U. S. 479, 501, i7 Sup. Ct. 896 , where the Supreme Court, speaking with reference to the power granted to the Interstate Commerce Commission, said: "The power given is partly judicial." See an article by A. A. Berle, Jr., entitled The Expansion of American Administrative Law (IgI7) $30 \mathrm{HARV}$. L. REv. 430, in which this point is discussed.

"The doctrine of the separation of powers does not prevent such a union of powers, for that doctrine applies only "so far as the requirements of efficient administration will permit." See 2 Willoughby, Constitution (1910) secs. 739, 742. And it would be utterly impractical to apply the doctrine to such special governmental machinery as the commissions which modern conditions have made necessary for an efficient administration of present-day governmental activities. The doctrine was engrafted into our law when nearly all governmental action was taken by the general governmental machinery which at that time was, in the main, adequate for the demands of the times. Since that time, however, and particularly within the last few decades, governmental action has been extended over a vast field which it had hitherto been supposed was beyond the reach of governmental interference. As a result we today have numerous commissions dealing with many great problems like those involved in rate regulation. It was inevitable of course that such an evolution should effect a change in the judicial process. It was impossible for the general governmental machinery to take much of the governmental action demanded by the times; and it would be impractical to the point of utter inefficiency to limit the action of these commissions so as to exclude many functions precisely like those exercised by the courts. Consequently these commissions today actually exercise numerous judicial functions. See A. A. Berle Jr., op. cit. note ro.

13 Prentis v. Atlantic Coast Line Co. (rg08) 2Ir U. S. 210, 29 Sup. Ct. 67.

${ }^{18}$ Reagan v. Farmers' Loan \& Trust Co. (1894) I54 U. S. 362, 14 Sup. Ct. I062. But see Mumn v. Illinois (1876) 94 U. S. 113 , as to an earlier view.

"See Corbin, Jural Relations and their Classification (I921) 30 YALE LAW Journat, 226. Cf. Kocourek, Various Definitions of Jural Relations (1920) 20 CoL. L. REv. 394 
stand on present or past facts. Can this mere change in time of action, then, change the nature of the action?

In holding that it does and that, therefore, such action is not judicial action, the United States Supreme Court, per Mr. Justice Holmes, reasoned as follows: $:^{15}$ The final act of fixing a rate, considered as an isolated act, is a legislative act, and

"The nature of the final act determines the nature of the previous inquiry. ... So, when the final act is legislative, the decision which induces it cannot be judicial in the practical sense, although the questions considered might be the same that would arise in the trial of a case."16

With great deference it is submitted that this reasoning is erroneous. In the first place it seems unsound to lay it down dogmatically that "the "nature of the final act determines the nature of the previous inquiry." The fallacy may be illustrated as follows: A public service commission is often empowered to establish reasonable rates if (in the ordinary administrative proceeding) it finds that the rate fixed by the utility is not a reasonable rate. Suppose, then, that in an ordinary proceeding such a commission, after due notice and hearing, passes upon the reasonableness of a rate fixed by the utility and decides that the rate is reasonable. Here the final act of the commission is clearly judicial, for the courts have always passed upon the reasonableness of rates fixed by a public utility. ${ }^{17}$ Hence, by the reasoning of the Supreme Court, the whole action of the commission is judicial.

Suppose, now, that in such a proceeding a commission, after finding that the rate fixed by the utility is a reasonable rate, then (with statutory authority) establishes that rate as the rate to be hereafter charged. Here the final act of the commission is legislative, for it lays down a rule for the future. ${ }^{18}$ Hence by the reasoning of the Supreme Court the whole proceeding of the commission becomes legislative, so that the determination by the commission that the rate fixed by the utility is reasonable is a legislative determination. In each case, however, the actual nature of the action of the commission in finding that the rate is reasonable is precisely the same sort of action in precisely the same sort of proceeding. It defies analysis, therefore, to say that the determination of the reasonableness of such a rate is in the one case judicial and in the other legislative. Ex rerum natura it would seem that the nature of action depends upon an analysis of the action at the time when

\footnotetext{
${ }^{25}$ Prentis v. Atlantic Coast Line Co.; supra note 12. ${ }^{16}$ Id., at p. 227.

17 "It has always been recognized that, if a carrier attempted to charge a shipper an unreasonable sum, the courts had jurisdiction to inquire into that matter. . . Nor [is] the limit of judicial inquiry altered, because the legislature instead of the carrier prescribes the rates." Reagan v. Farmers' Loan \& Trust Co., supra note $I_{3}$, at p. 397.

18 "The establishment of a rate is the making of a rule for the future, and therefore is an act legislative not judicial in kind." Per Mr. Justice Holmes in Prentis v. Atlantic Coast Line Co., supra note 12, at p. 226.
} 
its nature is called in question. It is submitted, therefore, that the question whether such action is legislative, executive, or judicial depends rather upon an analysis of the action at the time of the action than upon the nature of the subsequent action, if any, of the actor.

In the second place, the learned Justice says that the commission's determination 'of' the reasonableness of the rate which it contemporaneously establishes "cannot be judicial in the practical sense, although "the questions considered might be the same that would arise in the "trial of a case [in court]." But why? Whatever may be judicial in the sense in which the word judicial was used before anyone ever thought of conferring upon commissions the extensive powers now exercised by them, is not such action, to use the learned Justice's own phrase, "judicial in the practical sense"? As has been well said, this is a practical age, and it demands not only practical decisions but practical reasons to support them.

What action, then, is "judicial in the practical sense"? Mr. Justice Holmes, speaking for the court in the Prentis Case, answered the question as follows: :i $^{\text {ig }}$

"A judicial inquiry investigates, declares and enforces liabilities as they stand on present or past facts and under laws supposed already to exist."

Of course, if that definition of judicial action is literally accurate, it is difficult, if not impossible, to hold that such a determination as the one in question involves an exercise of judicial power. It seems clear, however, that the definition just quoted does not cover all cases. Suppose, for example, that a novel case arises in a common-law court. There is no statute on the question. The court must decide the case. The court, therefore, actually makes the law for that case; it does not, within Mr. Justice Holmes' definition, act "under laws supposed already "to exist." Of course, there are many who still say that a judge in such a case simply declares a preexisting law, but that theory is clearly fiction and should be discarded. Yet all agree that the action of a court in such a case is judicial action. Hence, in order to have judicial action it is not necessary that there should be, in point, a "law supposed "already to exist."

The practical difference between judicial and legishative action is that the former determines the "jural relations" of contestants "as "they stand on present or past facts," while the latter declares. rules for the future. ${ }^{21}$ Therefore, without attempting any all-comprehensive

${ }^{20}$ Ibid.

${ }^{20}$ See note I4 supra.

${ }^{21}$ As $\mathrm{Mr}$. Justice Field said in a dissenting opinion in the Sinking Fund Cases (1878) 99 U. S. 700, 76r: "The distinction between a judicial and a legislative act is well defined. The one determines what the law is and what the rights of parties are, with reference to transactions already had; the other prescribes what the law shall be in future cases arising under it. Wherever an act undertakes to determine a question of right or obligation, or of property, as the 
definition of judicial action, it is sufficient for present purposes to say that, since, as already shown, there may be judicial action before there is any "law" in existence in regard to the question, it would seem that, as the action in question, if taken by the commission after the rate is fixed, is indisputably judicial action, its nature cannot be changed merely because the action was taken in an earlier part of the commission's proceeding. For the purpose of determining the nature of such action it is immaterial in what stage of the proceeding such action is taken, for, at whatever stage this action is taken, there are contesting parties before the tribunal and the tribunal is, "in a practical sense," determining the jural relations of contestants "as they stand on present "or past facts." Hence, with Mr. Chief Justice Fuller in his dissenting opinion in the Prentis Case, ${ }^{22}$

"I cannot see why the reasonableness and justness of a rate may not be judicially inquired into and judicially determined at the time of the fixing of the rate, as well as afterwards."

If such a determination cannot be judicial, it is because of a distinction too subtle to be called "practical." It is submitted, therefore, that the modern public service commission in making a valuation and basing a rate thereon has contemporaneously made a judicial determination that the rate is reasonable and, therefore, non-confiscatory. Hence the question reduces itself to this: Does due process require a judicial review of such a judicial determination; and, if so, to what extent?

In the first case in point the United States Supreme Court held that die process requires a judicial review, but the Court did not declare the extent of the required review. ${ }^{23}$ In that case, however, which arose before commissions' functions were so extensive as at present, the Court proceeded on the theory that the action of the particular commission in fixing the rate was without semblance of due process, there being no notice or hearing. ${ }^{24}$ On that theory the Court was clearly correct in

foundation upon which it proceeds, such act is to that extent a judicial one, and not the proper exercise of.legislative functions." See adopting this distinction 2 Willoughby, op. cit. note II, sec. 744. See also Cooley, Constitutional Limitations. (7 ed. 1903) 132, 133, 134.

${ }^{22}$ Prentis v. Atlantic Coast Line Co., supra note I2, at p. 237.

${ }^{23}$ Chicago. Milwaukee \& St. Paul Ry. Co. v. Minnesota (18ga) I34 U. S. 4I8, Io Sup. Ct. 462,702 .

${ }^{24}$ Said the court (at p. 457): "No hearing is provided for [by the statute as construed by the supreme court of the state], no summons or notice to the company before the commission has found what it is to find and declared what it is to declare, no opportunity provided for the company to introduce witnesses before the commission, in fact, nothing which has the semblance of due process of law; and although, in the present case, it appears that, prior to the decision of the commission, the company appeared before it by its agent, and the commission investigated the rates charged by the company for transporting milk, yet it does not appear what the character of the investigation was or how the result was arrived at."

The statute, however, provided for a hearing before the commission. Minn. 
holding that the statute, in making such administrative action final, had deprived the utility of property without due process. The case, therefore, is not a good.precedent for the proposition that due process requires an independent judicial review of the administrative determinations of a modern public service commission, for the modern public service commission acts after due notice and hearing; and, in many respects, its proceedings are in a practical sense judicial proceedings. The courts in citing that case, however, have apparently failed to give due consideration to this findamental change in the proceedings of such commissions.

The later cases, so far as they touch upon the problem have, in the main, confined themselves to such indefinite generalizations as that "the right to a judicial review [under the due process clause] must be "substantial, adequate, and safely available."25

Although the Supreme Court, prior to the principal case, had never attempted to elucidate the extent to which due process requires a judicial review in rate regulation the Court had frequently used language which, apparently at least, is in accord with the dissent in the principal case. For example, in a rate case, much relied upon by the supreme court of the state to support the finding of the commission's valuation in the principal case, the United States Supreme Court said :26

"Its [the commission's] conclusion, of course, is subject to review, but, when supported by evidence, is accepted as final; not that its decision, involving, as it does, so many and such vast public interests, can be supported by a mere scintilla of proof, but the courts will not examine the facts further than to determine whether there was substantial evidence to sustain the order."

In the case just quoted from, however, there was no contention that the rate as fixed by the commission deprived the utility of any constitutional right. Now it needs no argument to show that in respect to the extent of required judicial review there is an essential difference between rate cases in which there is a claim of a violation of a constitutional right and rate cases in which there is no such claim. Hence, we may briefly dismiss those cases, like the case last quoted from, in which the courts, in the absence of a constitutional claim, have held that they would not review administrative determinations of fact further than to ascertain whether there was substantial evidence to sustain the commission's decision. Those cases do not involve due process or any other constitutional requirement. Courts and commentators, however, have commonly failed to distinguish carefully between these two classes of

Gen. Laws I887, ch. Io, sec. 9 (f). But the United States Supreme Court, accepting the construction placed upon the statute by the supreme court of the state, ignored this provision. 218.

${ }^{25}$ Wadley Southern Ry. v. Georgia (r9I5) 235 U. S. 65I, 66r, 35 Sup. Ct. 214,

${ }^{2}$ Interstate Commerce Commission v. Union Pacific R. R. Co. (19r2) $222 \mathrm{U} . \mathrm{S}$. 54I, 547, 32 Sup. Ct. I08, III. 
cases, with the result that we find it laid down in the leading text-book on rate regulation that

"A fundamental function of the Commission is to make findings of fact in the cases which come before it. Whether a rate is reasonable ... [and similar enumerated questions] are questions of fact, which are peculiarly within the province of the Commission. . . When based upon evidence, the Commission's determinations of facts are conclusive and will not be reexamined in the courts."27

Now, of course, if the statement just quoted is correct in regard to both classes of cases, then the decision in the principal case is clearly erroneous; for it is indisputable that the determination of the value of a public utility is a determination of a question of fact. However, the cases cited to support the proposition are largely cases in which the court was discussing the administrative determination of a disputed fact, such as "an essential jurisdictional fact," where there was no contention that the determination deprived the utility of some constitutional right. ${ }^{28}$ Indeed it seems that where a public service commission is alleged to have violated a constitutional right by a rate regulation, the Supreme Court has never held that "the courts will not examine "the facts further than to determine whether there was substantial "evidence to sustain the [commission's] order."

In analogous cases, however, the Supreme Court has taken that view. For example, in New York and Queens Gas Co. v. McCall, ${ }^{29}$ decided in I9I7, the Supreme Court took that view in regard to an order of a public service commission which required a public utility to extend its lines into new territory. In that case it was contended that such extension would not produce an adequate return and that, therefore, the extension order deprived the utility of property without due process. But the Court, after reviewing the cases, said : ${ }^{30}$

"It is the result of these and similar decisions that . . . this court . . . will not analyze or balance the evidence which was before the Commission for the purpose of determining whether it preponderates for or against the conclusion arrived at, yet it will, nevertheless, enter upon such an examination of the record as may be necessary to determine whether the federal constitutional right claimed has been denied, as, in this case, whether there was sueh a want of hearing or such arbitrary or capricious action on the part of the Commission as to violate the due-process clause of the Constitution."

". . Weagree with the Court of Appeals of New York in concluding that the action of the Commission complained of was not arbitrary or capricious, but was based on very substantial evidence, and therefore that, even if the courts differed with the Commission as to the expediency or wisdom of the order, they are without authority to substitute for its judgment their views of what may be reasonable or wise."

\footnotetext{
${ }^{27}$ Beale \& Wyman, Railroad Rate Regulation (2d ed. I9I5) sec. Ir34.

${ }^{28}$ One of the cases cited to support this proposition is Interstate Commerce Commission v. Union Pacific $R$. R. Co., supra note 26 , already discussed in the body of this article.

$\stackrel{2}{(1917)} 245$ U. S. $345,3^{8}$ Sup. Ct. r22.

${ }^{{ }^{\circ}} \mathrm{Id}$. at pp. $348,35 \mathrm{I}$.
} 
Though this is a holding in regard to an extension order and not in regard to a rate order, it would seem that there is, with respect to our present problem, no difference in principle between rate cases and extension cases. In each case an order of the same commission in precisely the same sort of proceeding is alleged to have deprived the utility of property without due process. It does not justify the difference in the decisions to say that the doctrine of stare decisis does not rigidly apply to due process cases-that what is due process in one case is not necessarily due process in another case. It may be that the line of demarcation between what is and what is not due process must be pricked out by the "process of judicial inclusion and exclusion." Yet the fundamental principles underlying due process should certainly be applied similarly in similar cases unless there is a very good reason to the contrary.

Is there, then, any good reason for applying these principles differently in rate cases? In this connection it must be remembered that a public service commission, through its special training or experience, is an expert body. ${ }^{32}$ It is specially designed and equipped to deal with a limited class of questions. It therefore has (theoretically at least) greater skill than the ordinary courts in dealing with the special questions within its limited jurisdiction. In short, the ordinary court is, so to speak, a sort of general practitioner; the commission is a specialist. It would seem, therefore, that a court, unless unmistakably required by the Constitution to do otherwise, should accord a wide margin of finality to the deliberate determinations of a body of specialists authorized by law to make such determinations. Does the Constitution, then, unmistakably prohibit such a margin of finality?

In arriving at the answer to that question it is necessary to bear in mind some of the fundamental conceptions underlying due process. In the first place it must be remembered that "due process is not "necessarily judicial process ;"33 that legislative, executive, or administrative process may be due process; and that the right of appeal to a court is not in all cases an essential of due process. ${ }^{34}$ Hence, even if the action of the commission in contemporaneously determining the reasonableness of the rate it establishes is not judicial process, it does not follow that the commission's determination is not due process or that there must necessarily.be a right of appeal to the courts. Furthermore, it must be remembered that the requirement of due process is not

${ }^{31}$ Davidson v. New Orleans (1877) 96 U. S. 97, 104; Twining v. State of New Jersey (Ig08) 2 II U. S. 78, 100, 29 Sup. Ct. 14, 20.

"People ex rel. Neze York \& Queens Gas Co. v. McCall (Igr6) 219 N. Y. 84, II3 N. E. 795, affirmed, and approved on this point, by the United States Supreme Court in New York \& Queens Gas Co. v. McCall, supra note 29. See Beale.\& Wyman, op. cit. note 27 , sec. Ir 34 .

${ }^{33}$ Reetz v. Michigan (1903) 188 U. S. 505, 507, 23 Sup. Ct. 390, 39x; Murray's Lessee v. Hoboken Land \& Improvement Co. (I855, U. S.) I8 How. 272; Davidson $v$. New Orleans, supra note 31 .

${ }^{34}$ Pittsburg etc. Ry. Co. v. Backus (1894) I54 U. S. 42I, I4 Sup. Ct. III4. See also cases cited in note 33. See 2 Willoughby, op. cit. note II, sec. 463 . 
necessarily a requirement that justice be accomplished; it is primarily a requirement that appropriate machinery be used for accomplishing justice. $^{35}$ And, as already explained, a highly specialized commission is a more appropriate machine than a general court for determining the special questions within its limited jurisdiction. Finally, the due process clause, like the Constitution of which it is a part, is, according to the better view, not a rigid, inelastic conception, but a living embodiment of supposedly fundamental principles which must be always applicable to the ever-changing conditions of society. ${ }^{36}$ As one of the greatest of living judges once expressed it, the due process clause was not intended to perpetuate any "particular [social or] economic "theory."37 Therefore, what was due process yesterday is not necessarily due process today; for to hold otherwise would, in the language of the Supreme Court, "stamp upon our jurisprudence the unchangeableness attributed to the laws of the Medes and Persians." 38 In other words, even if a given determination of the commission has not been hitherto considered due process, it does not follow that it is not due process today. Indeed it is impossible to follow the trend of judicial opinion without coming to the conclusion recently expressed by one writer as follows: : $^{39}$

"Most high courts have refused to regard constitutions as codes, and of late years have more and more made due process of law whatever process seems due to the demands of the times, as understood by the judges of the time being."

Can -it, then, be said that "the demands of the times" require that due process in rate valuations shall be a process in which there are not only due notice and a hearing in a proceeding judicial in nature (a proceeding specially designed for rate purposes), but also a right to an independent re-examination of the valuation by at ordinary court? Rather it would seem that the demands of the times require that the judicial tribunals should more and more accord a wide margin of finality to such administrative determinations. The United States Supreme Court and other courts have accorded this margin of finality to administrative valuations for purposes of condemnation, ${ }^{40}$ and for

${ }^{25}$ Cf: Davidson v. New Orleans, supra note $3 \mathrm{I}$, at p. 105: "It is not possible to hold that a party has, without due process of law, been deprived of his property, when, as regards the issues affecting, it, he has, by the laws of the state, a fair trial in a court of justice, according to the modes of proceeding applicable to such a case."

${ }^{38}$ See a discussion of this point by Charles M. Hough, Due Process of LawToday (rgrg) 32 HaRv. L. REv. 218.

${ }^{37}$ Holmes, J., dissenting in Lochner v. New York (1905) I98 U. S. 45, 75, 25 Sup. Ct. 539, 547: "A Constitution is not intended to embody a particular economic theory, whether of paternalism and the organic relation of the citizen to the state or of laissez faire. It is made for people of fundamentally differing views."

${ }^{28}$ Hurtado v. California (I884) IIo U. S. 516, 529, 4 Sup. Ct. III, II7.

20 Charles M. Hough, op. cit. note 36 , at p. 233.

"Long Island Water Supply Co. v. Brooklyn (I897) I66 U. S. 685, I7 Sup. Ct. 718. See 2 Lewis, Eminent Domain ( $3 \mathrm{~d}$ ed. Igog) sec. 788 , and authorities therein
cited. 
purposes of taxation.11 Why should they not accord it to valuations for purposes of rate regulation? In a taxation case ${ }^{42}$ in which there was a claim that the administrative valuation was unconstitutional, the United States Supreme Court held that it would not review such valuation further than to ascertain whether there was "fraud or a clear adoption of a fundamentally wrong principle."48 And in a condemnation case ${ }^{44}$ in which there was likewise a claim that the administrative valuation was a denial of due process the Supreme Court used the following significant langiage:

"It may be true, as contended, that, as construed by the Court of Appeals, the determination of the commissioners is conclusive as to the mere value of the property, but there is no denial of due process in making the findings of fact by the triers of fact, whether commissioners or a jury, final as to such facts, and leaving open to the courts simply the inquiry as to whether there was any erroneous basis adopted by the triers in their appraisal, or other errors in their proceedings." 45

Moreover, as we have seen, the Supreme Court accords this margin of finality to other administrative determinations than condemnation valuations and taxation valuations, and that, too, even where there is a claim that the administrative determination is a violation of due process. ${ }^{48}$

It is submitted, therefore, that the well-established view as to these analogous determinations, particularly as to taxation valuations and condemnation valuations, should be applied to rate valuations. In regard to all three valuations the owner's property is affected in substantially the same way, i. e., is actually "taken" by process of law; in regard to all three the administrative tribunal is simply determining a question of fact, viz., the value of the property, though, of course, the basis of the valuation may be different in the different classes of cases, e. g., market value in condemnation cases, and so-called "present value" in rate cases:

The very reason for creating commissions to make such determinations is that the efficient administration of government requires that such determinations be made by special tribunals as distinguished from the general governmental machinery. Hence, in regard to all three

"Pittsburg, Cincinnati, etc. Ry. Co. v. Backus (I894) supra note 34. See I Cooley, Taxation ( $3 d$ ed. Ig03) $6 \dot{4}, 65$ and authorities there cited.

"Chicago B. \& Q. Ry. Co. v. Babcock (Ig07). 204 U. S. 585, 27 Sup. Ct. 326.

¿Id. at p. 596.

"Long Island Water Supply Co: v. Brooklyn, supra note 40.

Id. at p. 695 .

"See, e.g., New York \& Queens Gas Co. v. McCall, supra note 29. See Hall, Cases on Constitutional Law (1913) 288, where there is an extended citation of authorities to support this statement: "In respect to controversies arising out of the administration of law on behalf of the public, not involving the punishment of offenses, due process of law is afforded, in the absence of fraud or other manifest abuse of authority, by submitting to an administrative tribunal the final determination of facts, after a fair hearing." 
valuations, and indeed in regard to all analogous determinations, it would seem that the practical-requirements of efficient government should furnish the basis of the extent to which the courts, under the requirements of due process, should review such so-called "administrative" action. ${ }^{4 \pi}$

The basic idea underlying the modern conception of due process with respect to deliberate legislative action seems to be that such action (at any rate if undelegated action) should not be held to violate due process, "unless, [as Mr. Justice Holmes once observed]" it can be "said that a rational and fair man" would "admit" that such action "would infringe fundamental principles as they have been understood "by the traditions of our people and our law." 8 Now, the final act of fixing a rate is deliberate legislative action. Why, therefore, apply. a different theory to such action when expressly authorized by the legislature and taken by a legislative agency which is admittedly more competent than the legislature itself to take such action? The United States Supreme Court has said with reference to such a legislative agency that its findings should be treated with the respect "due to the "judgment of a tribunal appointed by law and informed by expe"rience." " Hence, in declaring unconstitutional the deliberate action of such a tribunal it would seem that the courts should proceed with the utmost caution and with almost meticulous regard for the opinion of the commission. ${ }^{51}$ There is no reason why we should not go the length contended for by many courts and commentators with respect to undelegated legislative action, and say that deliberate "administrative" action should not be declared unconstitutional unless it is shown to be so "beyond a reasonable doubt." 52 At any rate, in view of the foregoing observations, especially in view of the decisions as to the finality of analogous administrative determinations, it is submitted that, when a public service commission acting within its jurisdiction and after due notice and hearing makes a valuation for purposes of rate regulation, nothing short of arbitrary action on the part of the commission or a clear adoption of a fundamentally wrong principle should be held to be such an infringement of a fundamental of the social order as to constitute a denial of due process.

"See 2 Willoughby, op. cit. note II, sec. 754 .

"In his dissenting opinion in Lochner v. New York, supra note 37, at p. 76.

"See Albert M. Kales, "Dive Process," the Inarticulate Major Premise and the Adamson,Act (IgI7) 26 Y ALE LAW Journal, 519; Charles M. Hough, $o p$. cit. note 36 , at pp. 232, 233.

${ }^{50}$ Illinois Central etc. R. R. Co. v. Interstate Commerce Commission. (I907) 206 U. S. 44r, 454, 27 Sup. Ct. 700, 704.

${ }^{51}$ Cf. Darnell v. Edwards (I9I7) 244 U. S. 564, 569, 37 Sup. Ct. 70r, 703, where the court says: "It is well established that in a question of rate-making there is a strong presumption in favor of the conclusions reached by an experienced administrative body after a full hearing."

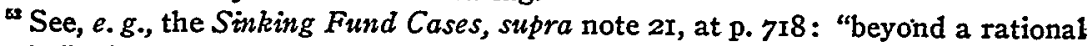
doubt." See James B. Thayer, The Origin and Scope of the American Doctrine of Constitutional Law (I893) 7 HARv. L. REv. I29, I39-I42. 